\title{
The Amaruk Project in Canada's New Pelly Bay Diamond District
}

\author{
B. Kienlen, E. Blackmore, N. Curry, G. Gill, M. Kolebaba, R. Lyon, C. Ozyer, Z. Pratt, R. \\ Vanderspiegel \\ Diamonds North Resources Ltd, Vancouver, Canada
}

World class diamond deposits are found in areas with specific geological settings, where there are numerous kimberlites, high ore grades, large tonnages and high stone values. Certain criteria can be used to recognize superior opportunities and focus on advancing these projects quickly. The criteria Diamonds North uses for distinguishing potential top tier targets are: mineral chemistry to provide indications of economic potential; numerous targets to ensure potential for a large kimberlite field; and tonnage potential as indicated by the size and shape of targets. The Amaruk project is in the heart of the emerging Pelly Bay Diamond District and can be viewed as a successful case study in the use of these criteria.

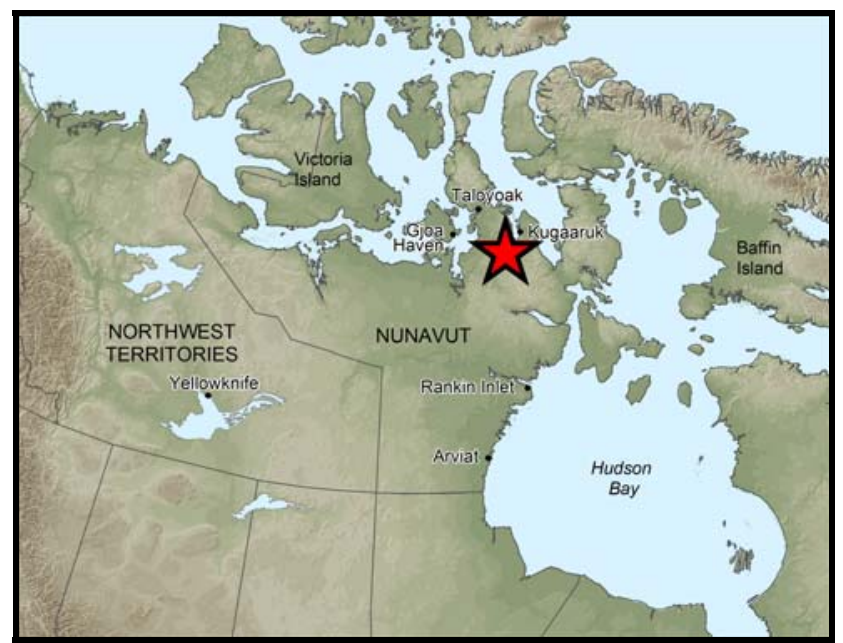

Figure 1: Project location. Red star indicates Amaruk project.

\section{Project History}

The Amaruk project was first staked by Diamonds North Resources Ltd in late 2003 and early 2004 (Figure 1). This was the result of regional till sampling results which indicated the southern extent of the Boothia Peninsula had been intruded by kimberlites that had sampled a potentially diamondiferous mantle. Since 2003, over 5000 till samples, 65,000 line kilometres of airborne geophysical data, and over 3000 line kilometres of ground based magnetic grids have been collected over the 1.9 million acre $(0.77$ million hectares) property.

\section{Geology}

The Pelly Bay Diamond District is within the Archean Rae Domain of the western Churchill Province that has been subjected to Paleoproterozoic successor sedimentation, magmatism, and tectonothermal reworking (Figure 2). Age dating by the Geological Survey of Canada shows constrained modeled ages of 2.7-3.2 Ga in the immediate project area (Hinchey et al., 2007). The Amaruk project is situated within the southern Boothia Uplift. Basement rocks are overlain by Paleozoic shelf deposits on Simpson Peninsula. A complex, four phase ice flow history is evident in the project area from the last glaciation (Tremblay et al., 2007). A thin till cover aids in tracking kimberlites while thick marine clay conceals a significant portion of the property. Three kimberlites have been dated radiometrically by the $\mathrm{Rb}-\mathrm{Sr}$ method on phlogopite as being Middle Cambrian (approximately 540Ma).

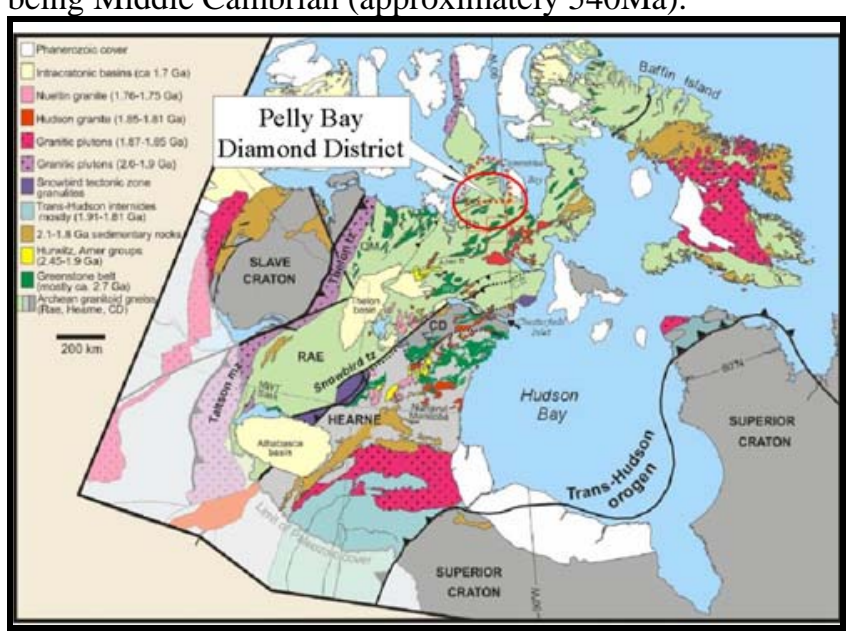

Figure 2: Generalized geology (modified from Berman et al., 2005)

\section{Economic Grade Potential}

A diamond bearing mantle and economic grade potential are evidenced by the significant number and distribution of high interest G10 garnets (Figure 3), DI chromites and chrome diopsides. 


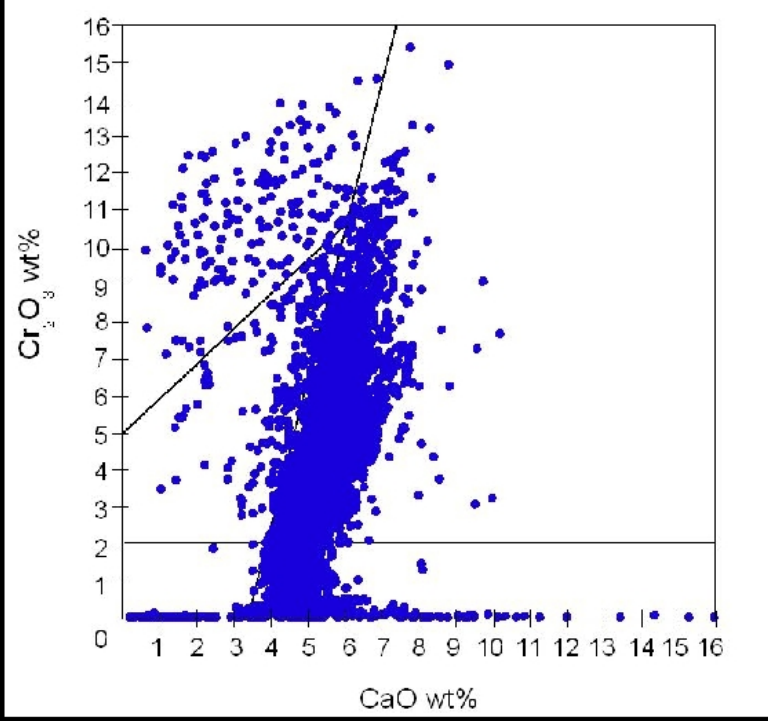

Figure 3: $\mathrm{CaO}$ vs $\mathrm{Cr}_{2} \mathrm{O}_{3}$ plot of all Amaruk garnets.

Detailed work on interpreting the underlying mantle has been ongoing with Diamonds North's expanding database collected from till samples and individual kimberlites. Kimberlites sampled to date are nearly all diamond bearing, and some are highly diamondiferous. A large proportion of the microdiamonds are of very high quality with exceptional characteristics. The majority of microdiamonds are clear octahedral forms with little resorption. Selected caustic fusion results are shown in Figure 4. Two clusters of kimberlites, Tuktu 1-4 and Qavvik 4-6 are being drill tested in 2008 with the intent of collecting 8-10 tonnes of kimberlite for evaluation. Indicator minerals from these bodies show very high proportions of high chrome-low calcium garnets and diamond inclusion type chromites.

\begin{tabular}{|l|c|c|c|c|c|c|c|c|c|}
\hline Kimberlite & $\begin{array}{c}\text { Weight } \\
(\mathrm{kg})\end{array}$ & Total & $\begin{array}{c}0.106 \\
\mathrm{~mm}\end{array}$ & $\begin{array}{c}0.150 \\
\mathrm{~mm}\end{array}$ & $\begin{array}{c}0.212 \\
\mathrm{~mm}\end{array}$ & $\begin{array}{c}0.300 \\
\mathrm{~mm}\end{array}$ & $\begin{array}{c}0.425 \\
\mathrm{~mm}\end{array}$ & $\begin{array}{c}0.600 \\
\mathrm{~mm}\end{array}$ & $\begin{array}{c}0.850 \\
\mathrm{~mm}\end{array}$ \\
\hline Tuktu-1 & 493.9 & 3400 & 1962 & 853 & 343 & 120 & 81 & 35 & 6 \\
\hline Tuktu-2 & 107 & 607 & 222 & 239 & 101 & 26 & 15 & 4 & 0 \\
\hline Tuktu-3 & 37.85 & 219 & 81 & 76 & 41 & 16 & 4 & 1 & 0 \\
\hline Tuktu-6 & 99.45 & 52 & 29 & 13 & 4 & 5 & 1 & 0 & 0 \\
\hline Qavvik-1 & 457.33 & 431 & 222 & 110 & 62 & 32 & 4 & 1 & 0 \\
\hline Qavvik-3 & 72.8 & 183 & 94 & 51 & 28 & 6 & 3 & 1 & 0 \\
\hline Qavvik-4 & 194.7 & 241 & 142 & 54 & 25 & 10 & 3 & 7 & 0 \\
\hline Qavvik-5 & 103.4 & 130 & 72 & 35 & 19 & 2 & 1 & 1 & 0 \\
\hline Qavvik-6 & 107.65 & 118 & 62 & 39 & 8 & 7 & 2 & 0 & 0 \\
\hline
\end{tabular}

Figure 4: Caustic results from RC cuttings of selected kimberlites

\section{Large Kimberlite Field Potential}

The possibility for a large number of kimberlites, thereby increasing the odds of economic bodies, is apparent based on the numerous kimberlite indicator mineral trains that have been identified in an area approximately $80 \mathrm{~km} \mathrm{x} 45 \mathrm{~km}$ within the central part of the property (Figure 5). After two drill seasons, 22 kimberlites have been discovered in five distinct areas of the property (Figure 6). Very high resolution airborne magnetic surveys have been highly successful in helping interpret the magnetically noisy bedrock environment and in recognizing hundreds of quality geophysical anomalies across the property. RC drills are employed to cost effectively test anomalies. Kimberlite float has been discovered across the property and provides another means of locating intrusions.

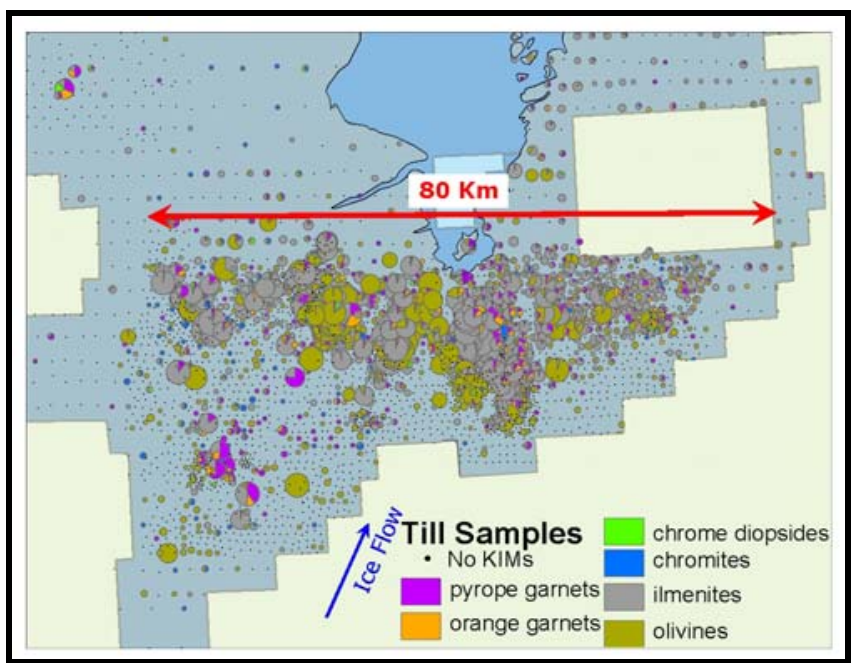

Figure 5: Indicator mineral distribution from till samples.

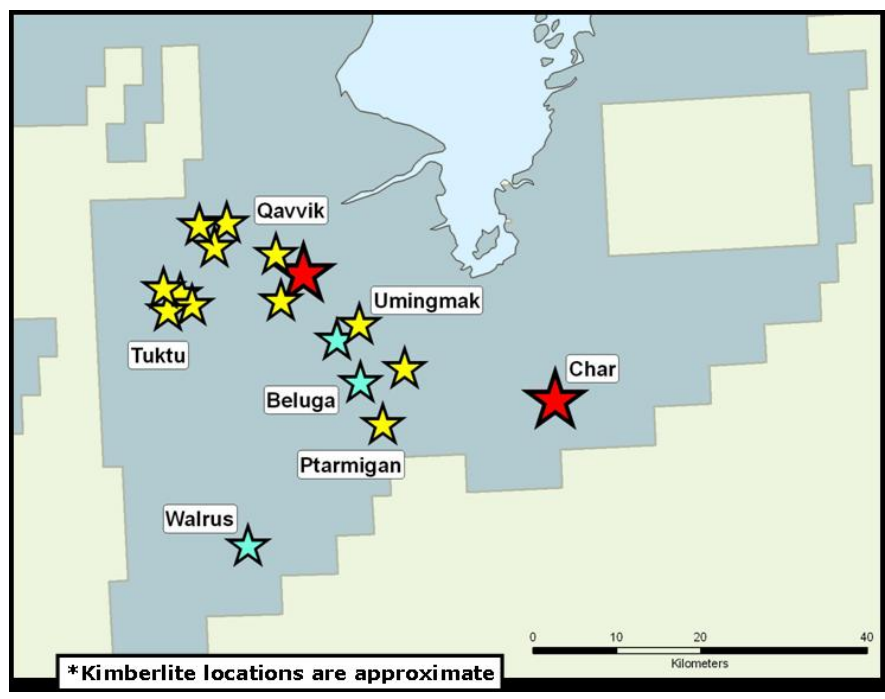

Figure 6: Kimberlite distribution.

\section{Tonnage Potential}

At this early exploration stage tonnage potential is beginning to be demonstrated by the number of kimberlites and their size estimates based on geophysical expression. Magnetic signatures indicate bodies from $<1$ to $>4 \mathrm{ha}$, and importantly, tightly spaced clusters are emerging such as the Tuktu 1-4 and Qavvik 4-6 kimberlites. Tuktu 1-3 may be the same kimberlite body based on early 2008 RC percussion drilling and a ground gravity survey. Diamond drilling may define the size of the kimberlites in these two clusters by the end of the 2008 season.

\section{Continuing Exploration}

To date, only a few kimberlites have been core drilled. They are generally highly altered coherent to tuffisitic bodies with abundant to rare macrocrysts. 
Serpentinized olivine macrocrysts sometimes have remnant fresh cores. Textures are generally massive with clearly defined interclast matrices of olivine phenocrysts (variably altered to serpentine), phlogopite, spinel/perovskite and crustal xenocrysts. Indicator minerals are visible, dominated by purplishred to pale pinkish garnets with kelyphytic rims, as well as chrome diopside and finer grained ilmenite visible under binocular lens. Abundance of rounded and altered mantle xenoliths is variable between bodies, dominated by peridotites - garnet lherzolite and possible dunites. Juvenile lapilli and hypabyssal fragments/autoliths are commonly observed. Country rock xenoliths comprise up to $15 \%$ of the core near the kimberlite margins.

Kimberlites that have been RC percussion drilled are less well described due to the typically $<1 \mathrm{~cm}$ sized chips. Indicator minerals in these chips are rarely seen although olivine or serpentinized olivine, are clearly observable and are used to differentiate kimberlite from other fine grained mafic intrusions. Some of the kimberlites are significantly more competent than others and show less alteration. Some float samples show flow banding textures and often contain large ilmenite macrocrysts.

Each season's drilling, till sampling and geophysical surveying campaigns have helped to refine the characteristics of the kimberlite signatures which will continue to guide Diamonds North toward further discoveries over the coming years.

\section{References}

Berman, R.G., Sanborn-Barrie, M., Stern, R.A., and Carson, C.J., 2005: Tectonometamorphism at ca. 2.35 and $1.85 \mathrm{Ga}$ in the Rae Domain, western Churchill Province, Nunavut, Canada; insights from structural, metamorphic and in situ geochronological analysis of the southwestern Committee Bay Belt; The Canadian Mineralogist, v. 43, p. 409-442

Hinchey, A.M. Ryan, J.J., Davis, W.J., Nadeau, L., and James, D.T., 2007: Detrital zircon geochronology of the Archean

volcano-sedimentary sequence of the Barclay belt and the Paleoproterozoic marble-quartzite sequence of the Northern Chantrey group, Boothia mainland area, Kitikmeot region, Nunavut: Geological Survey of Canada, Current Research 2007-C1, 19p.

Tremblay, T., Ryan, J.J. and James, D.T., 2007: Ice flow studies in Boothia Mainland (NTS 57A and 57B), Kitikmeot region, Nunavut, Geological Survey of Canada, Open File 5554, 16 pp. 